\title{
Intense photooxidative degradation of planktonic and bacterial lipids in sinking particles collected with sediment traps across the Canadian Beaufort Shelf (Arctic Ocean)
}

\author{
J.-F. Rontani ${ }^{1}$, B. Charriere ${ }^{1}$, A. Forest ${ }^{2}$, S. Heussner ${ }^{3}$, F. Vaultier ${ }^{1}$, M. Petit ${ }^{1}$, N. Delsaut ${ }^{3}$, L. Fortier ${ }^{2}$, and \\ R. Sempéré ${ }^{1}$ \\ ${ }^{1}$ Aix-Marseille Université, Université du Sud Toulon-Var, CNRS/INSU, UMR7294, IRD, MIO, UM110, 13288, Marseille, \\ Cedex 09, France \\ ${ }^{2}$ Université Laval, Takuvik CNRS-Laval U. Joint Laboratory, 1045 av. de la Médecine, Québec, Quebec G1V 0A6, Canada \\ ${ }^{3}$ Centre de Formation et de Recherche sur l'Environnement Méditerranéen (CEFREM, UMR CNRS 5110), Bât. U, \\ Université de Perpignan, Via Domitia (UPVD), 66860 Perpignan, France
}

Correspondence to: J.-F. Rontani (jean-francois.rontani@univ-amu.fr)

Received: 31 May 2012 - Published in Biogeosciences Discuss.: 26 June 2012

Revised: 22 October 2012 - Accepted: 29 October 2012 - Published: 23 November 2012

\begin{abstract}
The lipid content of seven samples of sinking particles collected with sediment traps moored at $\sim 100 \mathrm{~m}$ depth in summer and fall across the Canadian Beaufort Shelf (Arctic Ocean) was investigated. Our main goal was to quantify and characterize the biotic and abiotic degradation processes that acted on sinking material during these periods. Diatoms, which dominated the phytoplanktonic assemblage in every trap sample, appeared to be remarkably sensitive to Type II (i.e. involving singlet oxygen) photodegradation processes in summer, but seemed to be relatively unaffected by biotic degradation at the same time. Hence, the relative recalcitrance of phytodetritus towards biodegradation processes during the Arctic midnight sun period was attributed to the strong photodegradation state of heterotrophic bacteria, which likely resulted from the efficient transfer of singlet oxygen from photodegraded phytoplanktonic cells to attached bacteria. In addition, the detection in trap samples of photoproducts specific to wax ester components found in herbivorous copepods demonstrated that zooplanktonic faecal material exported out of the euphotic zone in summer were affected by Type II photodegradation processes as well. By contrast, sinking particles collected during the autumn were not influenced by any light-driven stress. Further chemical analyses showed that photodegraded sinking particles contained an important amount of intact hydroperoxides, which could then induce a strong oxidative stress in underlying sediments.
\end{abstract}

\section{Introduction}

Continental shelves of the Arctic Ocean receive a considerable amount of terrestrial matter from river runoff, mixed with important autochthonous production from microalgal photosynthesis during spring and summer (Rachold et al., 2004; Wassmann et al., 2004). The ongoing trend of declining sea ice extent and thickness in the Arctic Ocean appears to induce a steady increase in pelagic primary production (Arrigo et al., 2008), whereas permafrost thawing combined with enhanced river discharge are currently increasing the seaward flux of terrigenous material (Frey and McClelland, 2009). In turn, the annual lengthening of the ice-free period and the rise in river run-off could lead to an increase in particulate matter export that could modify the biogeochemistry and trophic balance of Arctic ecosystems through the coastal-marine realm (Vallières et al., 2008; Wassmann and Reigstad, 2011). Therefore, it is essential to understand how abiotic (autoxidation and photooxidation) and biotic (bacterial degradation) processes affect the dynamic of sinking fluxes of particulate organic matter in such environments.

Particles in the water column exist in a continuum of sizes (McCave, 1984), with two classes usually operationally recognized (Bacon et al., 1985; Wakeham and Lee, 1989): (i) suspended particles $\left(\leq 10^{2} \mu \mathrm{m}\right.$ diameter) sinking very slowly through the water column and constituting most of the standing stock of particulate matter in the ocean and (ii) sinking

Published by Copernicus Publications on behalf of the European Geosciences Union. 
particles $\left(\geq 10^{2} \mu \mathrm{m}\right.$ diameter) (including zooplankton fecal pellets and marine snow aggregates) numerically less abundant but responsible for most of the downward flux of material from the upper ocean to the sea floor. Suspended particles are typically collected by filtration, whereas sinking material is commonly collected using sediment traps. It may be noted that a continual exchange exists between these two particle classes owed to the complex suite of aggregation and disaggregation processes that occur in the water column (Wakeham and Lee, 1989; Hill, 1998). The sum of these processes affects particle settling velocity, residence time, and thus the efficiency of organic matter remineralization.

In a companion paper (Rontani et al., 2012b), we examined the lipid content of suspended particulate matter (SPM) samples collected in August 2009 in the Mackenzie River and in surface waters of the adjacent Beaufort Sea. Lipid biomarkers, although representing a very minor fraction of the total organic matter $(\mathrm{OM})$, convey important information on the source (terrigenous, marine or bacterial) and degradation state of OM, which is commonly more diagnostic than that provided by bulk parameters (Saliot et al., 2002). Using specific lipid degradation products that have been proposed for distinguishing biotic from abiotic processes (Rontani et al., 2011; Christodoulou et al., 2009), we showed that marine particulate organic matter (POM) was weakly degraded across the study area, while biodegradation and autoxidation processes acted intensely on terrigenous POM present in seawater (Rontani et al., 2012b). This result was unexpected as POM originating from land is generally considered to be well preserved due to its previous degradation during transit to the sea. In order to explain the specific induction of autoxidative processes on vascular plant-derived material, a mechanism involving homolytic cleavage of photochemically produced hydroperoxides resulting from the senescence of higher plants on land was proposed (Rontani et al., 2012b). This cleavage could be catalyzed by some redox active metal ions released from SPM in the mixing zone of riverine and marine waters. In contrast, the intense biodegradation of terrestrial POM observed was attributed to the well known (Bianchi, 2011) high "priming effect potential" of deltaic regions.

It was previously observed in the Mediterranean Sea (Rontani et al., 2009; Christodoulou et al., 2009) and the equatorial Pacific Ocean (Rontani et al., 2011) that the mechanisms of POM degradation vary according to particle size. In the present work, we present biogeochemical data based on specific lipid biomarkers studies for samples collected by sediment traps deployed at $100 \mathrm{~m}$ depth over the shelf of the Canadian Beaufort Sea and Amundsen Gulf during the period of August 2009 and October 2003.

\section{Material and methods}

\subsection{Study area}

The Canadian Beaufort Shelf (Fig. 1) represents around 2\% (i.e. $64000 \mathrm{~km}^{2}$ ) of the Arctic Ocean. The shelf is delimited on the west by the Mackenzie Canyon and on the east by Amundsen Gulf. The Mackenzie River is the largest river draining into the Arctic in terms of sediment and particulate organic carbon supply $\left(127 \times 10^{12} \mathrm{~g} \mathrm{y}^{-1}\right.$ of sediment and $2.1 \times 10^{12} \mathrm{~g} \mathrm{y}^{-1}$ of particulate organic carbon respectively; Macdonald et al., 1998) and the fourth largest in terms of freshwater discharge $\left(3.3 \times 10^{11} \mathrm{~m}^{3} \mathrm{y}^{-1}\right.$; Milliman and Meade, 1983; Brunskill, 1986; Macdonald et al., 1998). The Mackenzie River supplies about 95-99\% of the sediment to the Beaufort Shelf, with coastal erosion and other rivers (Hill et al., 1991; Rachold et al., 2004). The main river load occurs between end of May and the end of August with considerable interannual variance (O'Brien et al., 2006). Primary productivity over the Mackenzie Delta/Beaufort Shelf $\left(3.3 \times 10^{12} \mathrm{~g} \mathrm{y}^{-1}\right.$ of particulate organic carbon) is mainly due to phytoplanktonic blooms during late spring and summer (Macdonald et al., 1998). Production by ice algae accounts for less than $10 \%$ of the marine production in this area (Horner and Schrader, 1982).

\subsection{Sample collection}

Time series sediment traps (Technicap PPS 4/3; 24 cups; cylindrical-conical shape; collecting area: $0.125 \mathrm{~m}^{2}$ ) were deployed on 4 mooring lines located in the Amundsen Gulf (CA16, CA05) and on the Mackenzie Shelf (CA10, G09) in the Beaufort Sea (Fig. 1; Table 1). Baffled lids covered the opening of the sediment traps to reduce internal turbulence. Before deployment, sediment traps were thoroughly rinsed with freshwater and seawater following the JGOFS protocol (Knap et al., 1996). Sample cups were filled with filtered seawater (GFF $0.7 \mu \mathrm{m}$ ) adjusted to $35 \mathrm{PSU}$ with $\mathrm{NaCl}$. Formalin was added to preserve the material collected $(5 \% \mathrm{v} / \mathrm{v}$, sodium borate buffered).

\subsection{Sample treatment}

After retrieval, sample cups were checked for salinity and put aside $24 \mathrm{~h}$ to allow particles to settle down. Swimmers were removed from the samples then quantitative splitting into several fractions was completed using a McLane Wet Samples Divider or peristaltic pump. Subsamples for the determination of particulate organic carbon (POC) and lipids and their degradation products were filtered in triplicates through preweighted Whatman glass fiber filters (GFF $0.7 \mu \mathrm{m}, 25 \mathrm{~mm}$, combusted $4 \mathrm{~h}$ at $450^{\circ} \mathrm{C}$ ). For POC analysis, filters were dried for $12 \mathrm{~h}$ at $60^{\circ} \mathrm{C}$ and weighed again for dry weight. After exposure for $12 \mathrm{~h}$ to concentrated $\mathrm{HCl}$ fumes to remove inorganic carbon fraction, the samples were analyzed with a Perkin Elmer CHNS 2600 Series II. Total and 


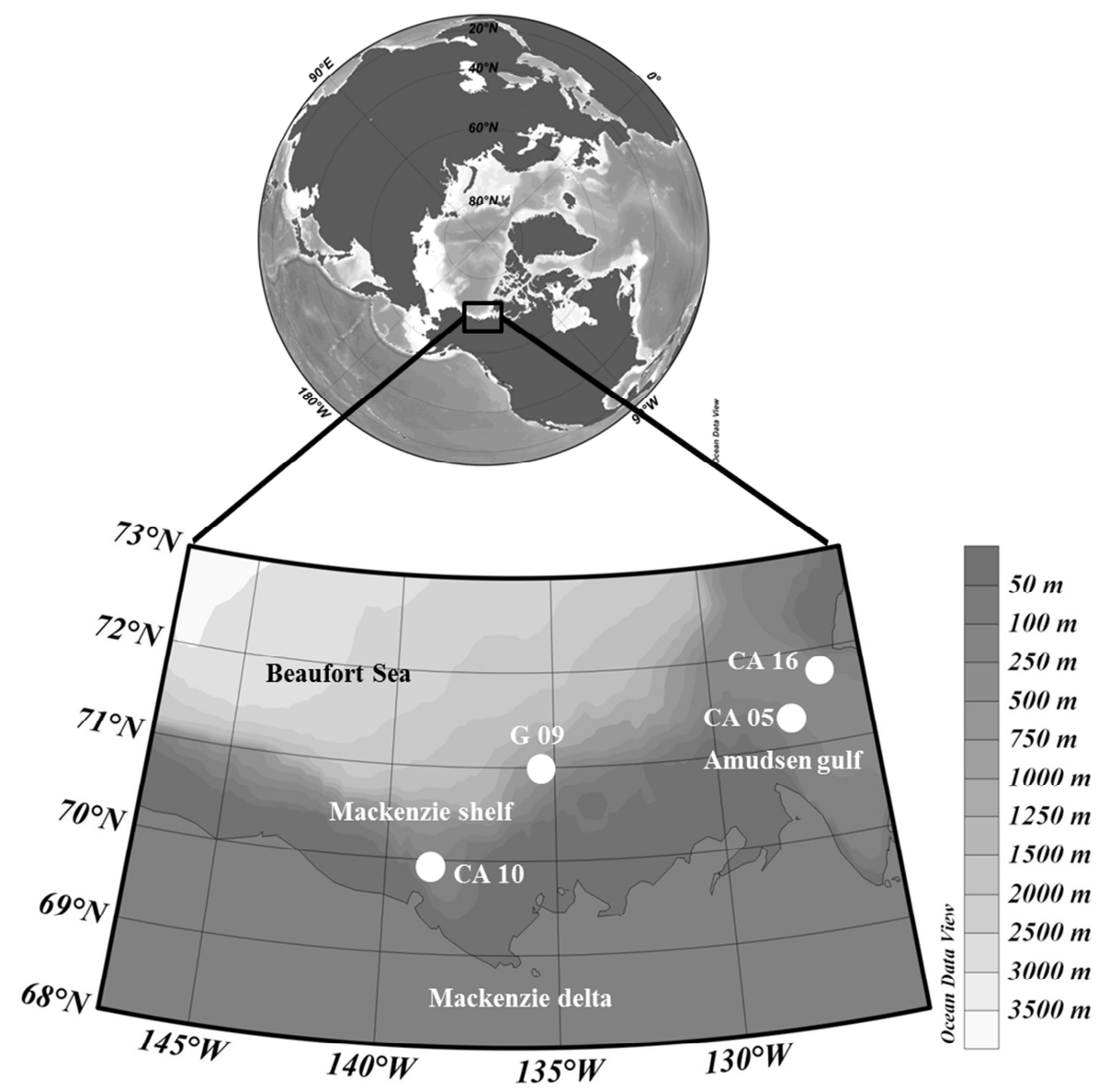

Fig. 1. Map of the studied area with locations of the different stations investigated.

Table 1. Mooring location and deployment information.

\begin{tabular}{|c|c|c|c|c|c|c|}
\hline Mooring & Location & Latitude & Longitude & Deployment period & Water depth (m) & Trap depth (m) \\
\hline CA05 A22 & Amundsen Gulf & 71.31245 & 127.58237 & 2 August 2009-7 August 2009 & 204 & 97.3 \\
\hline CA05 A23 & Amundsen Gulf & 71.31245 & 127.58237 & 8 August 2009-15 August 2009 & 204 & 97.3 \\
\hline CA05 A24 & Amundsen Gulf & 71.31245 & 127.58237 & 16 August 2009-31 August 2009 & 204 & 97.3 \\
\hline CA16 A23 & Amundsen Gulf & 71.78677 & 126.49695 & 8 August 2009-15 August 2009 & 314 & 110.2 \\
\hline G09 A2 & Mackenzie Shelf & 71.00254 & 135.47930 & 31 July 2009-14 August 2009 & 702 & 100.5 \\
\hline G09 A3 & Mackenzie Shelf & 71.00254 & 135.47930 & 30 August 2009-30 August 2009 & 702 & 100.5 \\
\hline CA10 A1 & Mackenzie Shelf & 69.95512 & 138.67373 & 7 October 2003-31 October 2003 & 250 & 105 \\
\hline
\end{tabular}

POC fluxes were expressed as daily fluxes $\left(\mathrm{mg} \mathrm{C} \mathrm{m}^{-2} \mathrm{~d}^{-1}\right)$ (Heussner et al., 1990; Lalande et al., 2009). The collected samples were processed in the laboratory according to the method described by Heussner et al. (1990). The total sample was divided into several aliquots to obtain different subsamples for analyzing total mass flux, TOC, lipids and their degradation products. Subsamples were filtered through a precombusted quartz fiber filter (Whatman GF/F, $0.7 \mu \mathrm{m}$ ) under low vacuum.

\subsubsection{Lipid extraction}

All solvents employed in this study were glass distilled analytical grade. Each filter was extracted four times with $\mathrm{CHCl}_{3}-\mathrm{MeOH}-\mathrm{H}_{2} \mathrm{O}(1: 2: 0.8, v / v / v)$ using ultrasonication (separation of particles and solvents by centrifugation at $3500 \mathrm{G}$ for $9 \mathrm{~min}$ ). To initiate phase separation after ultrasonication, $\mathrm{CHCl}_{3}$ and purified $\mathrm{H}_{2} \mathrm{O}$ were added to the combined extracts to give a final volume ratio of $1: 1: 0.9(v / v / v)$. The upper aqueous phase was extracted twice with $\mathrm{CHCl}_{3}$ and the combined $\mathrm{CHCl}_{3}$ extracts were dried over anhydrous 
$\mathrm{Na}_{2} \mathrm{SO}_{4}$, filtered and the solvent removed via rotary evaporation.

\subsubsection{Hydroperoxide-reduction}

$\mathrm{NaBH}_{4}$-reduction of the lipid extracts was carried out to reduce labile hydroperoxides resulting from photooxidation and autoxidation to alcohols that are amenable to gas chromatography-electron impact mass spectrometry (GCEIMS). The filters were put in methanol $(15 \mathrm{ml})$ and hydroperoxides were reduced to the corresponding alcohols by excess $\mathrm{NaBH}_{4}$ ( $70 \mathrm{mg}$ ) (30 min at room temperature). During this treatment, ketones are also reduced and the possibility of some ester cleavage cannot be excluded.

\subsubsection{Alkaline hydrolysis}

Metal ions can promote autoxidation during hot saponification procedures, so the prior reduction of hydroperoxides with $\mathrm{NaBH}_{4}$ allowed us to avoid such autoxidative artifacts during the alkaline hydrolysis. After $\mathrm{NaBH}_{4}$ reduction, $15 \mathrm{ml}$ of water and $1.7 \mathrm{~g}$ of potassium hydroxide were added and the mixture was directly saponified by refluxing for $2 \mathrm{~h}$. After cooling, the content of the flask was acidified with $\mathrm{HCl}(\mathrm{pH} 1)$ and subsequently extracted three times with dichloromethane. The combined dichloromethane extracts were dried over anhydrous $\mathrm{Na}_{2} \mathrm{SO}_{4}$, filtered and concentrated to give the total lipid fraction.

\subsubsection{Derivatization}

After solvent evaporation, residues were taken up in $300 \mu \mathrm{l}$ of a mixture of pyridine and N,Obis(trimethysilyl)trifluoroacetamide (BSTFA; Supelco) $(2: 1, v / v)$ and silylated for $1 \mathrm{~h}$ at $50^{\circ} \mathrm{C}$ to convert $\mathrm{OH}-$ containing compounds to their TMSi-ether derivatives. After evaporation to dryness under a stream of $\mathrm{N}_{2}$, the derivatized residues were taken up in a mixture of ethyl acetate and BSTFA (to avoid desilylation of fatty acids) for analysis using GC-EIMS. It should be noted that under these conditions steran- $3 \beta, 5 \alpha, 6 \beta$-triols were only silylated at the 3 and 6 positions and thus need to be analyzed with great care (Rontani et al., 2012b).

\subsubsection{Osmium tetroxide oxidation}

Double bond positions of monounsaturated fatty acids were determined unambiguously after $\mathrm{OsO}_{4}$ treatment. A fraction of total lipid extracts and $\mathrm{OsO}_{4}(1: 2, w / w)$ were added to a pyridine-dioxane mixture $(1: 8, v / v, 5 \mathrm{ml})$ and incubated for $1 \mathrm{~h}$ at room temperature. Then, $6 \mathrm{ml}$ of $\mathrm{Na}_{2} \mathrm{SO}_{3}$ suspension $\left(16 \% \mathrm{Na}_{2} \mathrm{SO}_{3}\right.$ in water-methanol, $\left.8.5: 2.5, v / v\right)$ was added and the mixture was again incubated for $1.5 \mathrm{~h}$. The resulting mixture was acidified ( $\mathrm{pH} 3)$ with $\mathrm{HCl}$ and extracted three times with DCM $(5 \mathrm{ml})$. The DCM extracts were combined and subsequently dried over anhydrous $\mathrm{Na}_{2} \mathrm{SO}_{4}$, filtered and concentrated.

\subsection{Gas chromatography-electron impact mass spectrometry (GC-EIMS)}

Compounds were identified by comparison of retention times and mass spectra with those of standards and quantified (calibration with external standards) by GC-EIMS. For low concentrations, or in the case of co-elutions, quantification was achieved using selected ion monitoring (SIM). GCEIMS analyses were carried out with an Agilent 6890 gas chromatograph connected to an Agilent 5973 Inert mass spectrometer. The following conditions were employed: $30 \mathrm{~m} \times 0.25 \mathrm{~mm}$ (i.d.) fused silica column coated with HP1-MS (Agilent; $0.25 \mu \mathrm{m}$ film thickness); oven temperature programmed in three sequential steps: (i) $70^{\circ} \mathrm{C}$ to $130^{\circ} \mathrm{C}$ at $20^{\circ} \mathrm{C} \mathrm{min}^{-1}$; (ii) $130^{\circ} \mathrm{C}$ to $250^{\circ} \mathrm{C}$ at $5^{\circ} \mathrm{C} \mathrm{min}^{-1}$; and (iii) $250^{\circ} \mathrm{C}$ to $300^{\circ} \mathrm{C}$ at $3^{\circ} \mathrm{C} \mathrm{min}^{-1}$; carrier gas (He) maintained at 0.69 bar until the end of the temperature program and then programmed from 0.69 bar to 1.49 bar at $0.04 \mathrm{bar} \mathrm{min}^{-1}$; injector (on column with retention gap) temperature $50^{\circ} \mathrm{C}$; electron energy $70 \mathrm{eV}$; source temperature $190^{\circ} \mathrm{C}$; cycle time 1.99 and 8.3 cycles s$^{-1}$ in SCAN and SIM modes, respectively.

\subsection{Lipid degradation products employed for photooxidation, autoxidation and biodegradation estimation}

$5 \alpha(\mathrm{H})$-stan- $3 \beta$-ols, $\Delta^{4}$-stera- $3 \beta, 6 \alpha / \beta$-diols and $3 \beta, 5 \alpha, 6 \beta$ steratriols (deriving from cholest-5-en-3 $\beta$-ol (cholesterol), 24 -ethylcholest-5-en-3 $\beta$-ol (sitosterol), 24-methylcholesta$5,22 E$-dien-3 $\beta$-ol (brassicasterol) and 24-methylcholesta5,24(28)-dien-3 $\beta$-ol (24-methylenecholesterol)) were used to estimate biodegradation, photooxidation and autoxidation state of the different components of the samples, respectively (Fig. 2) (Rontani et al., 2009, 2011; Christodoulou et al., 2009). Abiotic oxidation of the non-specific $\Delta^{9}$ monounsaturated fatty acids (oleic and palmitoleic acids) affords 8- $E, 8-Z, 9-E, 10-E, 11-E$ and $11-Z$ hydroxyacids (Frankel, 1998), which were employed to estimate the importance of autoxidation and photooxidation of bulk organic matter (Fig. 2) (Marchand and Rontani, 2001; Rontani et al., 2011). In contrast, abiotic oxidation of cis-vaccenic acid (a typical biomarker for Gram-negative bacteria, Sicre et al., 1988; Keweloh and Heipieper, 1996) produces 10-E, 10-Z, $11-E, 12-E, 13-E$ and $13-Z$ hydroxyacids, which were useful to estimate autoxidation and photooxidation state of bacteria (Fig. 2; Rontani et al., 2003; Christodoulou et al., 2010).

\subsection{Quantification of hydroperoxides and their ketonic and alcoholic degradation products}

A different treatment was employed to quantify hydroperoxides and their ketonic and alcoholic degradation products. 

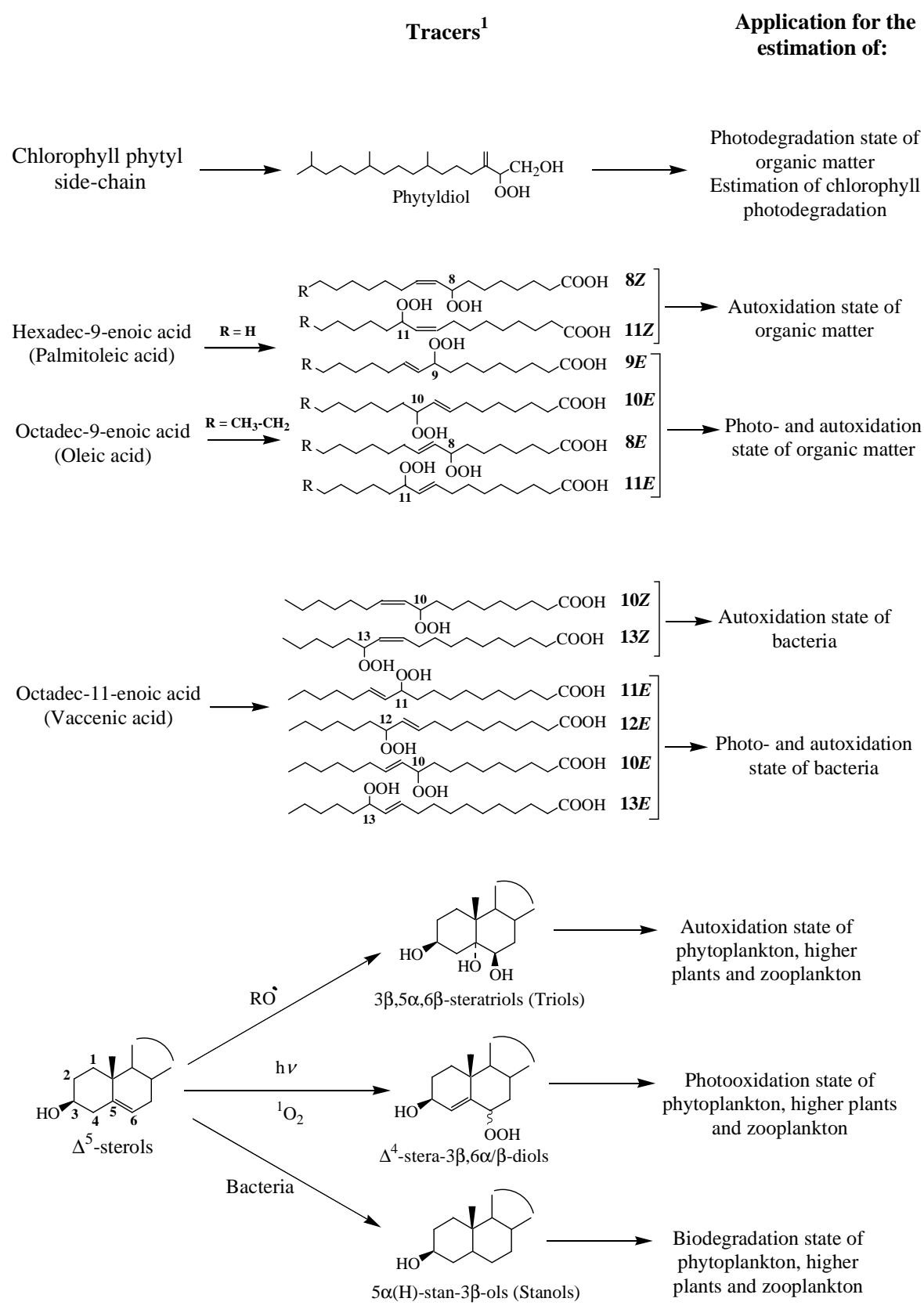

Fig. 2. Formulae, vernacular names and potential applications of the main (non-exhaustive list) lipid tracers of degradation processes employed in the present work. ${ }^{1}$ Quantified after $\mathrm{NaBH}_{4}$-reduction of hydroperoxides to the corresponding alcohols and subsequent silylation.

The residue obtained after extraction was dissolved in $4 \mathrm{ml}$ of dichloromethane and separated in two equal subsamples. After evaporation of the solvent, degradation products were obtained for the first subsample after acetylation (inducing complete conversion of hydroperoxides to the corresponding ketones, Mihara and Tateba, 1986) and saponification and for the second after reduction with $\mathrm{NaBD}_{4}$ and saponification. Comparison of the amounts of alcohols present after acetylation and after $\mathrm{NaBD}_{4}$ reduction made it possible to estimate the proportion of hydroperoxides and alcohols present in the samples, while after $\mathrm{NaBD}_{4}$-reduction deuterium labelling allowed to estimate the proportion of ketones really present in the samples (Marchand and Rontani, 2003).

Acetylation was carried out in $300 \mu \mathrm{l}$ of a mixture of pyridine and acetic anhydride $(2: 1, v / v)$, allowed to react at $50{ }^{\circ} \mathrm{C}$ overnight and then evaporated to dryness under nitrogen. 
Table 2. Relative percentage of sterols in the different samples.

\begin{tabular}{|c|c|c|c|c|c|c|c|}
\hline Sterols & CA05-A22 & CA05-A23 & CA05-A24 & CA16-A23 & CA01-A1 & G09-A2 & G09-A3 \\
\hline 24-Nor-cholesta-5,22E-dien-3 $\beta$-ol & 6.9 & 6.8 & 6.8 & 7.0 & 9.6 & 7.8 & 7.1 \\
\hline 27-Nor-24-methylcholesta-5,22E-dien-3 $\beta$-ol & 2.9 & 2.5 & 3.4 & 2.8 & 2.1 & 3.2 & 3.7 \\
\hline Cholesta-5,22E-dien- $3 \beta$-ol & 3.2 & 3.7 & 3.1 & 3.2 & 4.0 & 5.0 & 5.9 \\
\hline Cholesterol & 9.6 & 21.0 & 30.7 & 17.9 & 18.6 & 18.8 & 29.1 \\
\hline Brassicasterol & 5.6 & 5.9 & 5.0 & 6.3 & 3.9 & 8.3 & 5.8 \\
\hline 24-Methylenecholesterol & 10.1 & 12.4 & 9.0 & 9.1 & 6.5 & 11.0 & 15.2 \\
\hline Campesterol & 2.8 & 2.4 & 2.0 & 1.8 & 1.8 & 2.2 & 2.7 \\
\hline Stigmasterol & 5.9 & 5.1 & 4.3 & 5.9 & 5.4 & 5.6 & 3.8 \\
\hline Sitosterol & 45.0 & 33.5 & 28.3 & 39.2 & 38.8 & 31.5 & 22.5 \\
\hline Fucosterol & 8.1 & 6.7 & 7.4 & 6.8 & 9.3 & 6.6 & 4.2 \\
\hline
\end{tabular}

Table 3. Chlorophyll phytyl side-chain degradation products detected in the different samples and CPPI-based estimates of chlorophyll photodegradation.

\begin{tabular}{lccccccc}
\hline Mooring & $\begin{array}{c}4,8,12-\text { TMTD } \\
\text { acid }(\%)^{*}\end{array}$ & $\begin{array}{c}\text { Pristanic } \\
\text { acid }(\%)^{*}\end{array}$ & $\begin{array}{c}\text { Phytanic } \\
\text { acid }(\%)^{*}\end{array}$ & $\begin{array}{c}\text { Dihydrophytol } \\
(\%)^{*}\end{array}$ & $\begin{array}{c}\text { Pristane } \\
(\%)^{*}\end{array}$ & $\begin{array}{c}\text { CPPI } \\
\text { Chlorophyll } \\
\text { photodegradation \% }\end{array}$ \\
\hline CA05-A22 & 18.8 & 7.9 & 69.0 & 8.1 & 0.4 & $40.0 \pm 2.5$ & $99.8 \pm 0.1$ \\
CA05-A23 & 41.6 & 19.4 & 108.9 & 5.8 & 1.9 & $53.3 \pm 0.4$ & 100 \\
CA05-A24 & 66.1 & 39.2 & 72.7 & 11.5 & 3.1 & $35.6 \pm 3.7$ & $99.6 \pm 0.2$ \\
CA16-A23 & 55.0 & 27.4 & 87.3 & 15.9 & 2.4 & $104.1 \pm 0.1$ & 100 \\
G09-A2 & 37.2 & 27.9 & 218.9 & 5.4 & - & $120.9 \pm 41.7$ & 100 \\
G09-A3 & 37.6 & 10.1 & 110.5 & 6.7 & 14.2 & $36.7 \pm 4.9$ & $99.6 \pm 0.2$ \\
CA10-A1 & - & - & 120.0 & - & - & $22.7 \pm 9.9$ & $94.3 \pm 5.1$ \\
\hline
\end{tabular}

* Relative to phytol.

\section{Results and discussion}

\subsection{Classical lipid biomarker analyses}

\subsubsection{Sterols}

In the different samples investigated the major sterols were cholesterol (10-31\%) and sitosterol (28-45\%) (Table 2). Although a substantial amount of cholesterol may be derived from diatoms or Prymnesiophycean algae (Volkman, 1986), its dominance suggests an important contribution of zooplanktonic faecal material to these samples. Indeed, it is well known that zooplankton convert much of the sterols produced by algae into cholesterol (Volkman et al., 1980; Prahl et al., 1984). Sitosterol is commonly associated with terrestrial higher plants inputs (Lütjohann, 2004), but some microalgae (and notably diatoms) are now known to produce this sterol (Volkman, 1986, 2003). The other sterols, found in lower ranges in this study, include 24 nor-cholesta-5,22 $E$-dien-3 $\beta$-ol, 27 -nor-24-methylcholesta$5,22 E$-dien-3 $\beta$-ol, cholesta-5,22E-dien- $3 \beta$-ol, brassicasterol, 24-methylenecholesterol, 24-methylcholest-5-en-3 $\beta$-ol (campesterol), 24-ethylcholesta-5,22 $E$-dien- $3 \beta$-ol (stigmasterol) and 24-ethylcholesta-5,24(28) $E$-dien-3 $\beta$-ol (fucosterol) (Table 2). 24-nor-cholesta-5,22-dien-3 $\beta$-ol, has been previously identified in a phytoplankton sample composed principally of diatoms (Boutry et al., 1971). The important contribution of diatoms to these samples is also well supported by the presence of brassicasterol and 24methylenecholesterol, which are major constituents of several diatom species (Lee et al., 1980). However, it may be noted that brassicasterol is also present in some dinoflagellates and in many haptophytes (Volkman, 1986, 2003). If the lack of dinosterol, which is present in some dinoflagellates (Mansour et al., 1999), does not support the presence of such organisms, a significant contribution of dinoflagellates to the samples cannot be totally excluded since they do not systematically produce dinosterol (Leblond and Chapman, 2002). In contrast, a contribution of haptophytes to the samples is very likely. Indeed, it was previously observed that larger haptophytes and diatoms co-dominated in near-surface assemblages of the Beaufort Sea in summer (Hill et al., 2005).

\subsubsection{Isoprenoids}

Dihydrophytol, pristane, 3,7,11,15-tetramethylhexadecanoic (phytanic), 2,6,10,14-tetramethylpentadecanoic (pristanic) and 4,8,12-trimethyltridecanoic (4,8,12-TMTD) acids could be detected in most of the total lipid extracts analysed (Table 3). The presence of relatively high proportions of these degradation products of the chlorophyll phytyl side-chain well supports the contribution of zooplanktonic faecal pellets 
Table 4. Flux $\left(\mu \mathrm{g} \mathrm{m}^{-2} \mathrm{~d}^{-1}\right)$ of fatty acids and $n$-alkan-1-ols.

\begin{tabular}{|c|c|c|c|c|c|c|c|}
\hline Compounds & CA05-A22 & CA05-A23 & CA05-A24 & CA16-A23 & CA10-A1 & G09-A2 & G09-A3 \\
\hline \multicolumn{8}{|l|}{ Fatty acids } \\
\hline $\mathrm{C}_{14: 0}$ & 227.2 & 802.0 & 317.9 & 523.6 & 16.5 & 275.3 & 404.2 \\
\hline $\mathrm{C}_{15: 0}$ & 35.4 & 99.2 & 86.3 & 160.3 & 19.1 & 32.8 & 85.3 \\
\hline $\mathrm{C}_{16: 1 \Delta 9}$ (Palmitoleic) & 465.3 & 1066.5 & 306.8 & 570.9 & 81.8 & 457.2 & 507.7 \\
\hline $\mathrm{C}_{16: 0}$ & 971.0 & 2907.3 & 1024.7 & 4572.9 & 506.6 & 1581.8 & 1443.4 \\
\hline $\mathrm{C}_{17: 1}$ & - & 21.8 & 38.5 & - & 11.4 & - & - \\
\hline $\mathrm{C}_{17: 0}$ & 14.1 & 39.5 & 36.3 & 95.3 & 15.0 & 23.2 & - \\
\hline $\mathrm{C}_{18: 1 \Delta 9}$ (Oleic) & 170.4 & 438.2 & 248.3 & 442.8 & 183.1 & 181.6 & 353.1 \\
\hline $\mathrm{C}_{18: 1 \Delta 11}$ (Vaccenic) & 73.4 & 310.5 & 114.3 & 183.8 & 55.1 & 82.2 & 167.8 \\
\hline $\mathrm{C}_{18: 1 \Delta 13}$ & 12.0 & 88.1 & 34.7 & 62.0 & 15.6 & 18.2 & 41.7 \\
\hline $\mathrm{C}_{18: 0}$ & 368.6 & 992.1 & 172.5 & 1999.0 & 131.0 & 451.1 & 260.6 \\
\hline $\mathrm{C}_{20: 1 \Delta 11}$ & 34.0 & 123.3 & 79.8 & 217.5 & 68.9 & - & - \\
\hline $\mathrm{C}_{20: 0}$ & 6.0 & 17.4 & 10.5 & 49.8 & 6.7 & 12.0 & 9.2 \\
\hline $\mathrm{C}_{22: 1 \Delta 11}$ & 5.7 & 23.7 & 16.1 & 28.6 & 3.8 & 5.6 & 21.7 \\
\hline $\mathrm{C}_{22: 0}$ & 4.7 & 12.4 & 4.2 & 31.4 & 3.2 & 6.9 & 6.6 \\
\hline $\mathrm{C}_{24: 1 \Delta 11}$ & 3.3 & 37.7 & 18.3 & 14.3 & 2.0 & 5.7 & 26.3 \\
\hline $\mathrm{C}_{24: 0}$ & 2.7 & 16.4 & 5.8 & 41.3 & 4.9 & 7.2 & 5.7 \\
\hline \multicolumn{8}{|l|}{$n$-Alkan-1-ols } \\
\hline $\mathrm{C}_{14: 0}$ & 5.3 & 105.2 & 73.9 & 94.3 & 15.9 & 24.6 & 236.2 \\
\hline $\mathrm{C}_{16: 1}$ & 7.8 & 81.3 & 46.1 & 61.5 & 5.2 & 29.1 & 109.8 \\
\hline $\mathrm{C}_{16: 0}$ & 58.9 & 357.1 & 273.8 & 408.1 & 32.1 & 122.6 & 471.0 \\
\hline $\mathrm{C}_{18: 0}$ & 25.1 & 117.4 & 46.0 & 257.3 & 23.1 & 62.0 & 81.7 \\
\hline $\mathrm{C}_{20: 1 \Delta 11}$ & 122.0 & 204.6 & 186.2 & 111.6 & 66.0 & 20.4 & 130.7 \\
\hline $\mathrm{C}_{22: 1 \Delta 11}$ & 605.9 & 500.4 & 217.5 & 120.9 & 43.8 & 20.7 & 213.7 \\
\hline
\end{tabular}

to the sampling material. Indeed, pelagic crustaceans decrease the abundance of the chlorophyll phytyl side-chain when feeding herbivorously (Prahl et al., 1984; Harvey et al., 1987; Bradshaw et al., 1990). Any phytol remaining in the faeces of pelagic zooplankton after herbivorous feeding will be quickly removed on subsequent reprocessing of the faecal material (Bradshaw and Eglinton, 1993). Several phytol degradation products have been thus identified in zooplanktonic faecal pellets during feeding experiments, including pristane, isomeric pristenes, isomeric phytadienes, dihydrophytol and phytanic, pristanic, 4,8,12-TMTD and isomeric phytenic acids (for a review see Rontani and Volkman, 2003).

\subsubsection{Fatty acids and $n$-alkan-1-ols}

Total lipid extracts of the different samples exhibited a distribution of even-carbon number dominated fatty acids ranging from $\mathrm{C}_{14}$ to $\mathrm{C}_{24}$ (Table 4), suggesting the presence of a material dominated by marine organisms (plankton and bacteria). Long-chain $\left(>\mathrm{C}_{24}\right.$ ) saturated fatty acids, which are characteristic of epicuticular waxes of terrestrial higher plants (Kolattukudy, 1977; Gagosian et al., 1987), could not be detected. The three dominant monounsaturated fatty acids appeared to be hexadec-9cis-enoic (palmitoleic), octadec9cis-enoic (oleic) and octadec-11cis-enoic (vaccenic) acids (Table 3). Palmitoleic and oleic acids have numerous pos- sible biological origins (plants, fungi, yeasts, bacteria, animals or algae) (Harwood and Russell, 1984), while vaccenic acid is a typical biomarker for Gram-negative bacteria (Sicre et al., 1988; Keweloh and Heipieper, 1996). Small amounts of the very unusual octadec-13-enoic acid could be also detected (Table 4). The production of this compound was previously observed during linolenic acid biohydrogenation by rumen microorganisms (Ward et al., 1964). In these samples it could thus result from biohydrogenation of phytoplanktonic linolenic acid in the gut of large calanoid copepods that feed herbivorously and dominate the zooplankton assemblage in the area (Forest et al., 2012a). Despite the apparent strong contribution of diatom and zooplankton material to the samples (see previous sections), polyunsaturated fatty acids (PUFA) were not detected. The lack of these compounds could be attributed to their well known, very high reactivity towards photooxidation (Kawamura and Gagosian, 1987) and autoxidation (Frankel, 1998) processes and to the intense abiotic degradation state of the samples investigated (see Sect. 3.2).

Interestingly, although sinking particles are generally considered as the main contributors to the sedimentary record (Wakeham and Lee, 1989), after $\mathrm{OsO}_{4}$ treatment of the different trap samples investigated, we failed to detect significant amounts of monounsaturated fatty acids with a trans double bond, which were previously observed in surface 
sediments of this zone in very high proportions (Rontani et al., 2012a). The isomerization process responsible for the formation of trans monounsaturated fatty acids seems thus to act in sediments and not in sinking particles.

Four principal types of storage lipids have been found in marine zooplankton: triacylglycerols, wax esters, phospholipids and diacylglycerol ethers (Lee et al., 2006). Wax esters are generally the major storage lipids in high latitude species (Lee et al., 2006). The most common alkan-1-ols of the wax esters found in herbivorous zooplankton are $\mathrm{C}_{20: 1 \Delta 11}$ and $\mathrm{C}_{22: 1 \Delta 11}$, while omnivorous or carnivorous zooplankton have a predominance of $\mathrm{C}_{14: 0}$ and $\mathrm{C}_{16: 0}$ alkan-1-ols (Lee and Nevenzel, 1979; Albers et al., 1996). $C_{20: 1 \Delta 11}$ and $C_{22: 1 \Delta 11}$ alcohols are only known to occur in copepods that undergo diapause (Graeve et al., 1994), which are largely distributed in the Arctic. The detection of high proportions of these two specific compounds in most of the total lipid extracts (Table 4) confirmed the presence of high amounts of herbivorous zooplanktonic material in the different samples. The source of this material is probably lipid droplets remaining "trapped" in faecal pellets (Najdek et al., 1994) produced by the large herbivorous copepods Calanus hyperboreus and $C$. glacialis that undergo diapause.

\subsection{Lipid degradation product analyses}

\subsubsection{Chlorophyll}

Although the visible light-dependent degradation rate of the chlorophyll tetrapyrrole ring is three to four times higher than for its phytyl side-chain (Cuny et al., 1999), no specific and stable tetrapyrrole photodegradation products could be identified in the literature. Type II photosensitized oxidation (i.e., involving ${ }^{1} \mathrm{O}_{2}$ ) of the phytyl side-chain, however, leads notably to the production of 3-methylidene7,11,15-trimethylhexadecan-1,2-diol (phytyldiol) (Rontani et al., 1994). Phytyldiol is ubiquitous in the marine environment and constitutes a stable and specific tracer for photodegradation of chlorophyll phytyl side-chain (Rontani et al., 1996; Cuny and Rontani, 1999). Further, the molar ratio phytyldiol: phytol (Chlorophyll Phytyl side-chain Photodegradation Index, CPPI) was proposed to estimate the extent of chlorophyll photodegraded in natural marine samples (Cuny et al., 2002).

CPPI ranges from 36 to 121 in the case of the samples collected in summer (Table 3 ). These values are particularly high when compared with CPPI previously measured in particulate matter collected in summer in the Equatorial Pacific (Rontani et al., 2011) and in the northwestern Mediterranean Sea (Cuny et al., 2002) (ranging from 1 to 8 and from 1 to 24 , respectively). This attests to the exceptional efficiency of photooxidation processes in the Arctic Ocean region in summer, most probably because of the midnight sun that persists for 3 months (May-July) at $70^{\circ} \mathrm{N}$. On the basis of these very high CPPI values, it could be estimated that during this
A

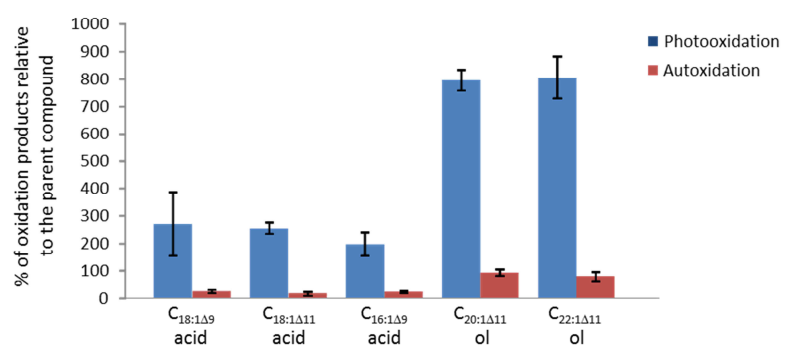

B

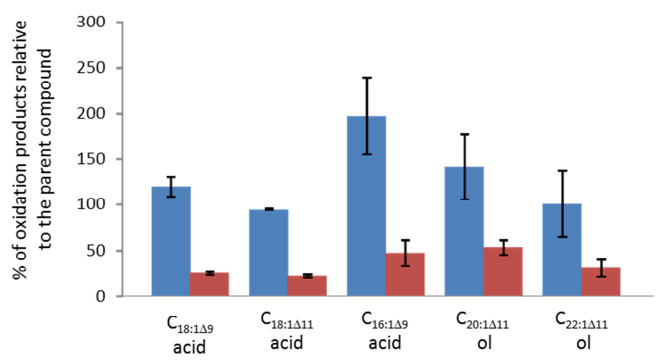

Fig. 3. Percentages of photooxidation and autoxidation products (relative to the residual parent compound) of monounsaturated fatty acids and alkan-1-ols observed in G09-A2 (A) and G09-A3 (B) samples.

period chlorophyll was practically entirely photodegraded in sinking particles (Table 3). In the sample CA10 A1 collected in October, a strong photodegradation state of chlorophyll (>94\%) was also observed (Table 3).

\subsubsection{Monounsaturated fatty acids and $\boldsymbol{n}$-alkan-1-ols}

Due to the lack of specificity of palmitoleic and oleic acids, their oxidation products have been used to assess abiotic degradation of bulk OM. The results obtained are summarized in Figs. 2-4. Photooxidation percentages of these two acids appeared to be very high (values ranging from 45 to $270 \%$ relative to the residual parent compound) in summer, but not in fall (values $<20 \%$ ). These results, which are in good agreement with the total photodegradation of chlorophyll observed in summer (Table 3), confirm that during this period, photooxidation processes act very intensely on sinking particles of the Beaufort Sea. Autoxidation (free radical oxidation) processes also contributed to the degradation of these two fatty acids $(10-30 \%)$, but to a lesser extent than light-driven degradation (Figs. 3-5). The strong spatial variability in the photooxidation stress (Figs. 3-5) could likely be attributed to differences in water clarity at the different sampling stations that typically increases from a shelf-edge location (CA05), to a mid-slope area (CA16), up to a basin-close environment (G09) (Table 1). Alternatively, visual inspection of sediment trap samples revealed that particles collected at 
A

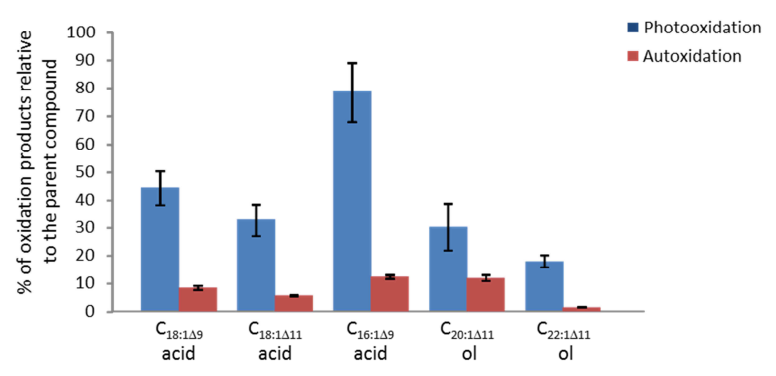

B

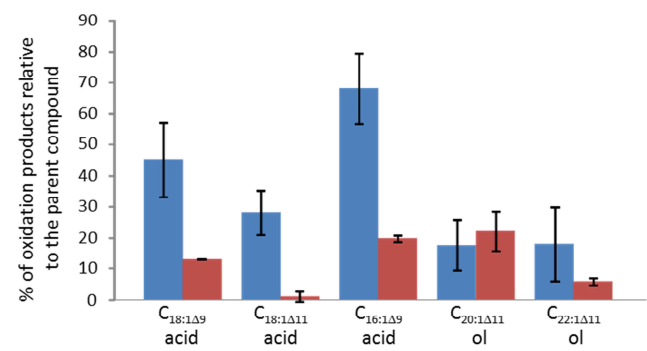

C

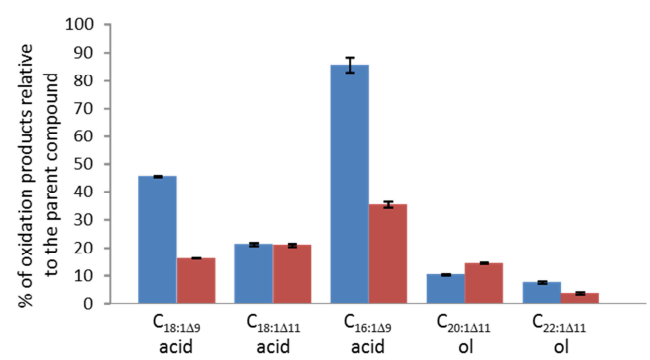

Fig. 4. Percentages of photooxidation and autoxidation products (relative to the residual parent compound) of monounsaturated fatty acids and alkan-1-ols observed in CA05-A22 (A), CA05-A23 (B) and CA05-A24 (C) samples.

G09 were generally finer and less aggregated than at CA16 and CA05, with the latter being obviously affected by the sinking of large diatom colonies (A. Forest, personal observation, 2009). Organic matter contained in large aggregates could then be relatively more protected against photooxidation than in fine particles that might offer a high surface-tovolume ratio.

Oxidation products of vaccenic acid allowed us to estimate photo- and autoxidation state of heterotrophic bacteria associated to sinking particles. These bacteria were also strongly photodegraded in summer (photodegradation percentage ranging from 45 to $260 \%$ ) (Figs. 3-5) and weakly in fall (photodegradation percentage $<10 \%$ ). During the summer period, transfer of singlet oxygen from senescent phytoplanktonic cells to bacteria (Rontani et al., 2003; Christodoulou et al., 2010) seems thus to have been especially efficient. Vaccenic acid also appeared to be affected by autoxidation but less intensively (Figs. 3-5). Indeed, reaction of singlet oxygen with unsaturated components of the outer
A

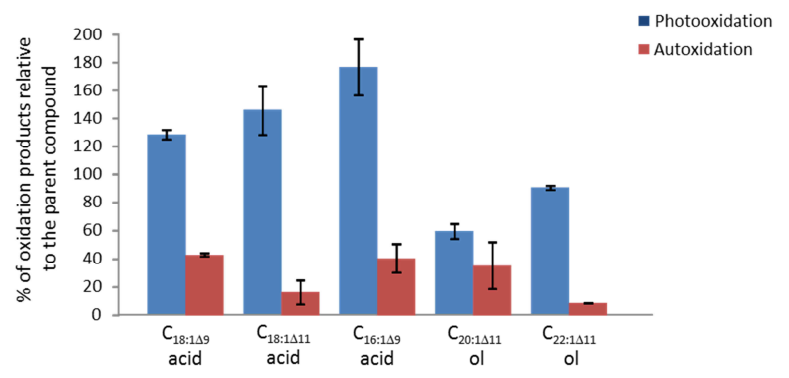

B

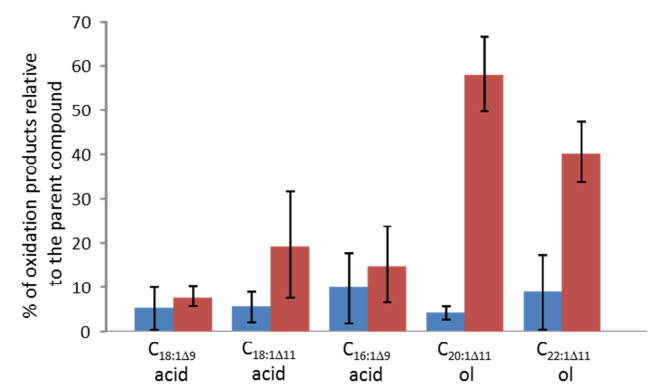

Fig. 5. Percentages of photooxidation and autoxidation products (relative to the residual parent compound) of monounsaturated fatty acids and alkan-1-ols observed in CA16-A23 (A) and CA10-A1 (B) samples.

lipopolysaccharide membrane of Gram negative bacteria (the dominant bacteria in the ocean) leads to the formation of reactive secondary products, such as peroxyl radicals, which may in turn accentuate cell death (Dahl et al., 1989). The intense oxidative stress resulting from singlet oxygen damages in bacteria should limit their growth (and thus biodegradation processes) during the settling of sinking particles.

Important amounts of oxidation products of $\mathrm{C}_{20: 1 \Delta 11}$ and $\mathrm{C}_{22: 1 \Delta 11}$ alkan-1-ols (values ranging from 10 to $800 \%$ of the residual parent compound), which are specific components of zooplankton wax esters (Lee and Nevenzel, 1979; Albers et al., 1996), could be also detected in the different samples (Figs. 3-5). The major part of these compounds results from the involvement of Type II (i.e. involving singlet oxygen) photoprocesses (Fig. 6). It is important to note that these oxidation products disappeared when the alkaline hydrolysis step was avoided during the treatment. These results clearly showed that photooxidation processes acted directly on wax esters and not on the corresponding $n$-alkan-1-ol after enzymatic hydrolysis. The high efficiency of Type II photooxidation processes in such micro-environments may be attributed to: (i) the high concentration of wax esters in the droplets trapped in faecal pellets (as discussed above) favoring the likelihood of interaction between singlet oxygen (produced from chlorophyll and phaeopigments contained in the pellets) and their double bonds and (ii) the apolar character of 


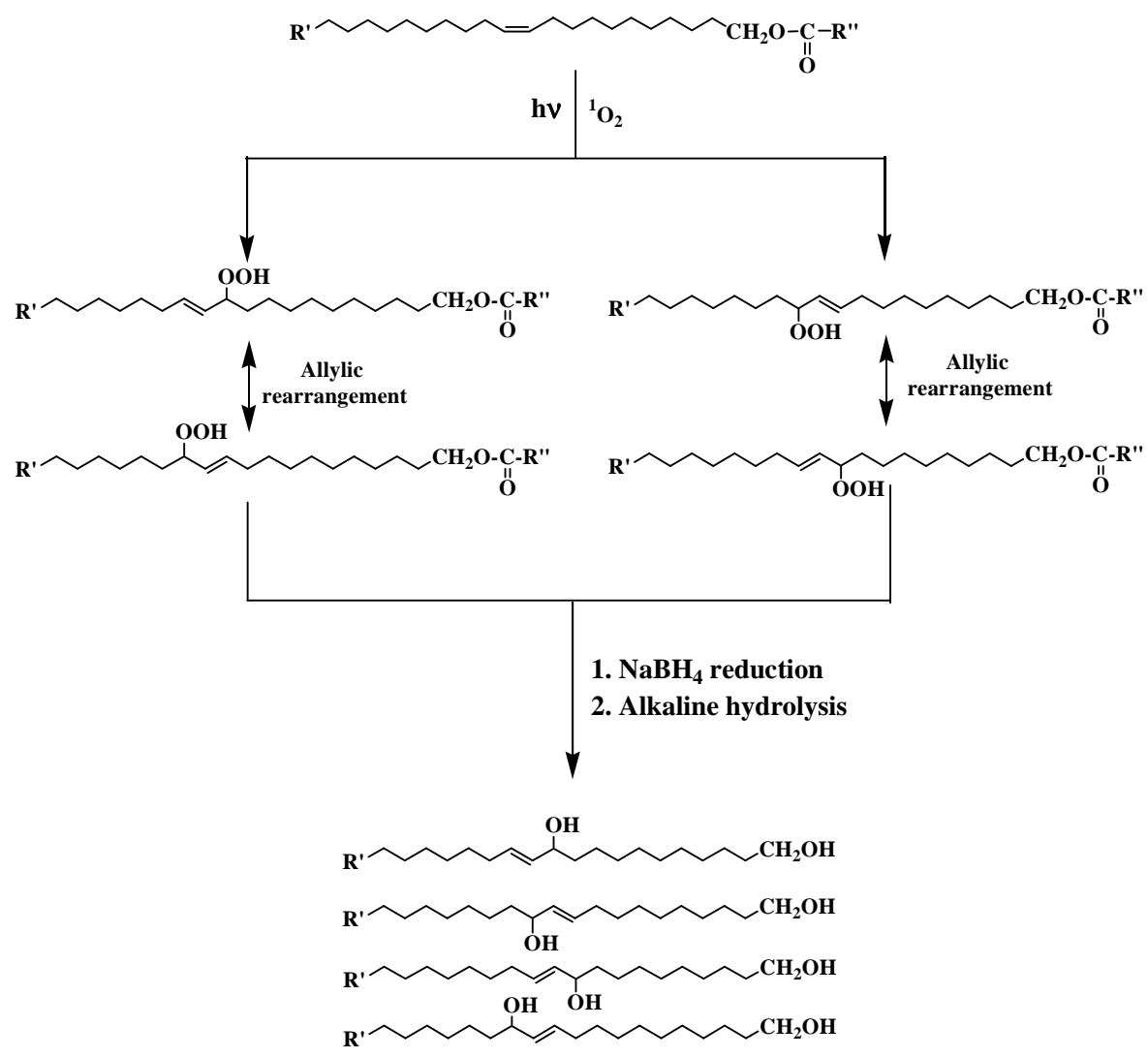

$\mathbf{R}=$ Polyunsaturated alkyl chain
$\mathbf{R}^{\prime}=\mathrm{CH}_{3}-$ or $\mathrm{CH}_{3}-\left(\mathrm{CH}_{2}\right)_{2^{-}}$
$\mathbf{R}^{\prime \prime}=$ Highly photooxidized polyunsaturated alkyl chain

Fig. 6. Type II (i.e. involving singlet oxygen) photooxidation of $C_{20: 1 \Delta 11}$ and $C_{22: 1 \Delta 11}$ alkan-1-ols.

these droplets. Indeed, the lifetime of singlet oxygen in apolar environments is longer, and its potential diffusion distance greater, than under polar conditions (Suwa et al., 1977). To our knowledge, this is the first in situ demonstration of photodegradation of zooplanktonic faecal material.

Allylic hydroperoxides resulting from photo- and autoxidation of monounsaturated fatty acids may undergo: (i) heterolytic cleavage catalyzed by protons (Frimer, 1979) leading to the formation of $\omega$-oxocarboxylic acids and other volatile products, and (ii) homolytic cleavage induced by transition metal ions (Pokorny, 1987; Schaich, 2005) or UVR (since hydroperoxides absorb in the UVR range; Horspool and Armesto, 1992). Homolytic cleavage of hydroperoxyacids would lead to the formation of alkoxyl radicals, which can then: (i) abstract a hydrogen atom from another molecule to give hydroxyacids, (ii) lose a hydrogen atom to yield ketoacids, or (iii) undergo $\beta$-cleavage reaction affording volatile products. It may be noted that hydroxyacids and ketoacids may also result from disproportionation of two alkoxyl radicals. During $\mathrm{NaBH}_{4}$-reduction (carried out in order to avoid thermal breakdown of hydroperoxides during the treatment), hydroperoxides and ketones were reduced to the corresponding alcohols. The sum of hydroperoxy acids, ketoacids and hydroxy acids was thus quantified in the form of hydroxyacids. A different treatment was employed (see Sect. 2.6.) in order to specifically quantify hydroperoxyacids and their main degradation products: hydroxyacids and ketoacids. The results obtained in the case of the sample G09A2 are summarized in Fig. 7a. It appears that in sinking particles, a significant proportion (ranging from 12 to $22 \%$ of the sum of hydroperoxides, ketones and alcohols) of oxidation products of monounsaturated fatty acids are still under the form of hydroperoxides. An important flux of these compounds should thus reach the seafloor, inducing a strong oxidative stress in surface sediments. These results support the mechanisms proposed in our companion paper to explain the presence of unusual very high proportions of epoxyacids and monounsaturated fatty acids with a trans double bond in 
A

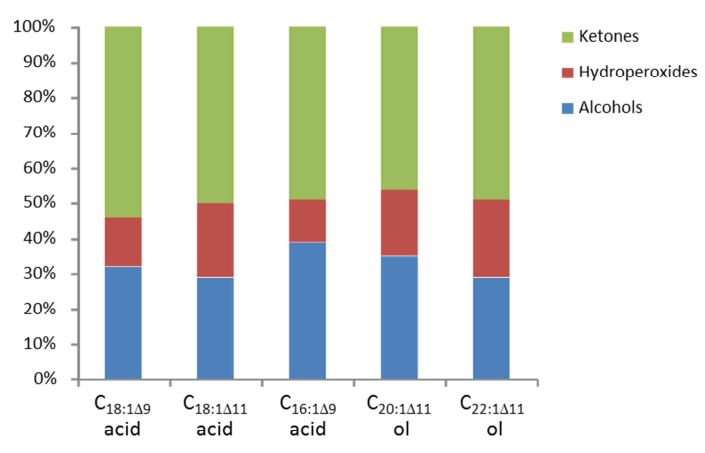

B

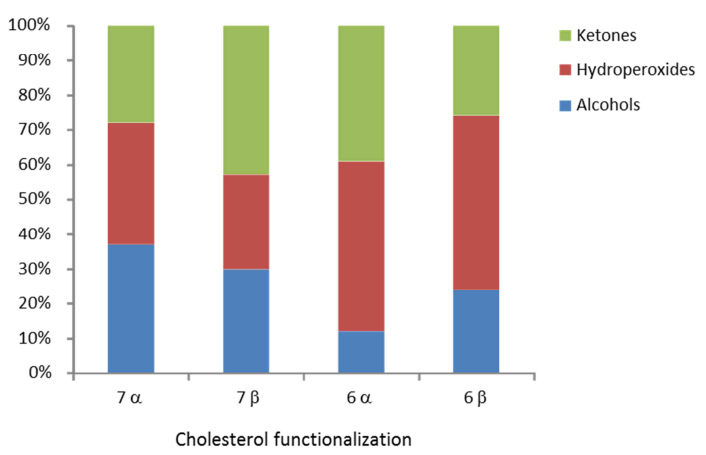

Fig. 7. Relative percentages of intact hydroperoxides and their ketonic and alcoholic degradation products measured in the case of monounsaturated fatty acids and alkan-1-ols (A) and cholesterol (B) oxidation products.

sediments of this zone (Rontani et al., 2012a). Indeed, the formation of the formers was attributed to the involvement of enzymes catalyzing epoxidation of unsaturated fatty acids in the presence of alkylhydroperoxides as co-substrates, and this of the latters to cis/trans isomerization reactions induced by thiyl radicals resulting from the reaction of thiols with hydroperoxides.

\subsubsection{Sterols}

Degradation products of four model $\Delta^{5-}$ sterols (cholesterol, 24-methylenecholesterol, brassicasterol and sitosterol) were quantified. The results obtained are summarized in Fig. 8. Photooxidation of $\Delta^{5-}$ sterols appears less important than that of chlorophyll phytyl side-chain or monounsaturated fatty acids (see Sects. 3.2.1 and 3.2.2). Indeed, degradation rate constants of ${ }^{1} \mathrm{O}_{2}$-mediated photooxidation (type II photoreactions) are generally lower for $\Delta^{5-}$ sterols than for chlorophyll phytyl side-chain and monounsaturated fatty acids (Rontani et al., 1998), possibly due to steric hindrance during the attack of the sterol $\Delta^{5}$ double bond by ${ }^{1} \mathrm{O}_{2}$ (Beutner et al., 2000). Photodegradation processes acted more intensively on 24-methylenecholesterol (mainly arising from diatoms) (photodegradation percentage ranging from
40 to $81 \%$ relative to the parent sterol) than on brassicasterol (arising from diatoms and/or Prymnesiophytes) (values ranging from 18 to $33 \%$ ) (Fig. 8). These differences suggest a higher efficiency of photodegradation processes in diatoms than in Prymnesiophytes. The similarity observed between the overall behaviors for brassicasterol and sitosterol (Fig. 8) with respect to degradation well supports a major contribution of Prymnesiophytes to sitosterol. Interestingly, the sitosterol and campesterol contained in suspended particles collected in this zone (mainly arising from terrestrial higher plants) were strongly autoxidized (Rontani et al., 2012b). The lack of sitosterol autoxidation products in all the total lipid extracts obtained from sediment trap samples thus confirms that terrestrial higher plant material does not contribute significantly to this sterol in sinking particles. A release of sub-Arctic terrestrial POM in two different pools was recently proposed (Vonk et al., 2010a, b). A pool composed of mineral-bound POC derived from erosion, which has short initial residence times in the surface water and quickly settles to the sea floor, and another pool composed of higher plants debris mainly contributing to suspended particulate matter. These two pools probably settle too quickly or too slowly, respectively, to contribute significantly to the material collected by the different traps deployed.

Low proportions of $5 \alpha$-stanols corresponding to 24methylenecholesterol and brassicasterol could be observed in the different samples (values ranging from 3 to $15 \%$ of the corresponding sterol) (Fig. 8). These values, which are very close to those generally considered as typical of healthy phytoplanktonic cells (5-10\%, Wakeham et al., 1997), suggest that biodegradation processes acted only very weakly on phytoplanktonic material. The lack of the corresponding ster-4-en-3-ones, which are classical bacterial metabolites of $\Delta^{5}$-sterols (de Leeuw and Baas, 1986; Wakeham, 1989) often detected in sinking particles (Bayona et al., 1989; Christodoulou et al., 2009), well supports this assumption. This apparently good resistance of phytodetritus against bacterial degradation might result from the inhibition of bacterial growth when ${ }^{1} \mathrm{O}_{2}$ generated by the photolysis of senescent phytoplanktonic cells in the euphotic zone is efficiently transferred to attached bacteria, as it was observed in the previous section.

As in the case of monounsaturated fatty acids, the specific proportion of hydroperoxysterols and their alcoholic and ketonic degradation products have been also determined. The results obtained are summarized in Fig. $7 \mathrm{~b}$. Hydroperoxysterols appeared to be more stable than hydroperoxyacids in sinking particles (Fig. 7a); significant amount of these compounds should thus reach the sediments. This observation is in good agreement with the previous detection of intact hydroperoxysterols in recent surficial sediments (Rontani and Marchand, 2000). While ratio $\Delta^{4}$ $6 \alpha / 6 \beta$-hydroperoxides/ $\Delta^{5}-7 \alpha / 7 \beta$-hydroperoxysterols produced during irradiation of senescent phytoplanktonic cells ranged from 0.30 to 0.35 (Rontani et al., 1997), very high 

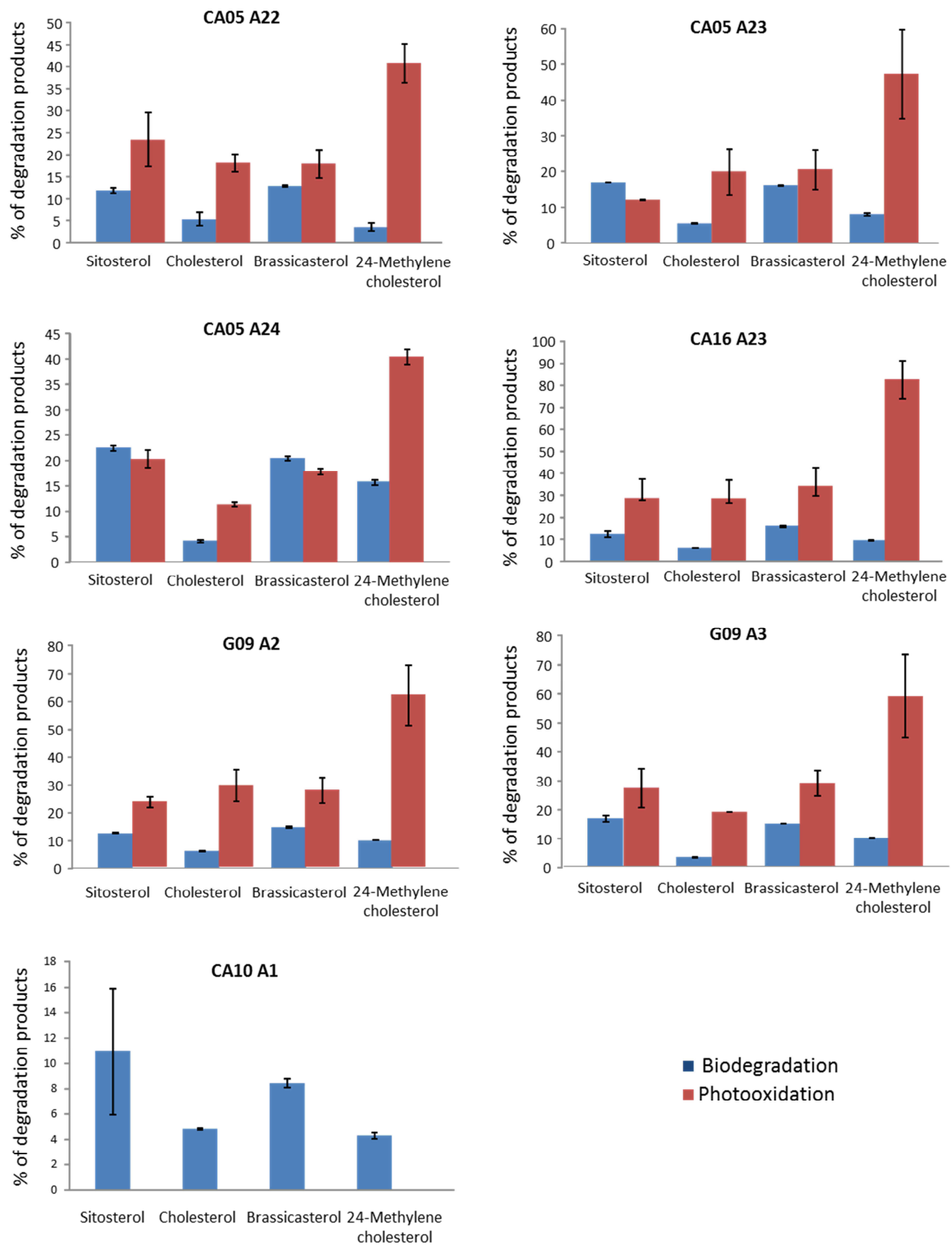

Fig. 8. Percentages of photooxidation and autoxidation products (relative to the residual parent compound) of sitosterol, cholesterol, brassicasterol and 24-methylenecholesterol in the different samples investigated.

values (ranging from 0.4 to 2.55 ) of the ratio cholest-4en-3 $\beta, 6 \alpha / 6 \beta$-diols/cholest-5-en- $3 \beta, 7 \alpha / 7 \beta$-diols were previously measured (after $\mathrm{NaBH}_{4}$-reduction) in sediment trap samples collected in Mediterranean Sea (Christodoulou et al., 2009). These high values were attributed to a faster degradation of $\Delta^{5}$-7-hydroperoxysterols than $\Delta^{4}-6$ hydroperoxysterols during settling through the water column (Christodoulou et al., 2009). According to the theoretical stability of the alkyl radicals formed during $\beta$-scission of the corresponding alkoxyl radicals, the following order of stabil- ity was tentatively proposed by Christodoulou et al. (2009): $\Delta^{4}$-6-hydroperoxysterols $>\Delta^{5}$-7-hydroperoxysterols $>\Delta^{6}$ 5-hydroperoxysterols. The results obtained in the present study (Fig. 7b) well support this assumption. 


\section{Conclusions}

Lipids and their degradation products were quantified in seven samples of sinking particles collected with sediment traps in summer and fall across the Canadian Beaufort Shelf. These samples were dominated by diatoms and zooplanktonic faecal pellets. Terrestrial higher plants resulting from Mackenzie River discharge did not contribute significantly to the sinking material. During the summer period, Type II (i.e. involving singlet oxygen) photooxidation processes acted strongly on senescent phytoplanktonic cells, heterotrophic bacteria and zooplanktonic faecal material. Diatoms, which dominated the phytoplanktonic assemblage, appeared to be remarkably sensitive to photodegradation. Singlet oxygen transfer from phytodetritus to attached bacteria was particularly efficient inducing strong oxidative damages in these heterotrophic organisms. The presence of high amounts of photoproducts of $\mathrm{C}_{20: 1 \Delta 11}$ and $\mathrm{C}_{22: 1 \Delta 11}$ alcohols, which are specific components of wax esters found in herbivorous copepods (Lee and Nevenzel, 1979; Albers et al., 1996), allowed us to demonstrate for the first time the high efficiency of Type II photodegradation processes in zooplanktonic faecal material.

In contrast, phytoplanktonic cells seemed to be relatively preserved towards biodegradation processes in sinking POM. As proposed by Rontani et al. (2011), there is a synergy between senescing phytoplanktonic cells and attached bacteria and between photooxidation and biodegradation. Photolysis of chlorophyll in senescing algal cells produces singlet oxygen, which if transferred from algal cells to attached bacteria may inhibit bacterial growth and reduce the extent of heterotrophic degradation. Therefore, it seems that there is a direct link between the photooxidation state of lipids of senescent phytoplanktonic cells in particles and their resistance towards biotic degradation. However, this does not exclude that the flux of labile dissolved organic matter produced through the photo-cleavage of phytodetritus might sustain an active community of free-living bacteria around sinking particles (as proposed by Forest et al., 2012b).

In addition, we demonstrated that strongly photodegraded sinking particles contained an important amount of intact hydroperoxides. After sedimentation, these compounds should induce a strong oxidative stress in surface sediments, which could be at the origin of the formation of epoxyacids and monounsaturated fatty acids with a trans double bonds previously detected in unusual high proportion in this zone (Rontani et al., 2012a).

In order to put the current global warming trend into the context of natural climate variability, it is essential to reconstruct sedimentary palaeoenvironments. Lipid biomarkers preserved in bottom sediments are particularly useful for this purpose, since they represent the ultimate signature of sympagic and pelagic productivity (e.g. Volkman et al., 1998; Wakeham et al., 1997; Rontani and Volkman, 2005; Bianchi and Canuel, 2011). However, reconstructions based on sedi- ment biomarkers are incomplete without a careful consideration of particle alteration and/or preservation during their transport from the euphotic zone to the benthic boundary layer. It is thus critical to understand how biotic and abiotic processes may alter the environmental signal encoded by the biomarker proxy. This is particularly important for Arctic regions, which indeed provide the earliest and most dramatic manifestations of global change (Hansen et al., 2012). Here, we have observed an extraordinary efficiency of photooxidation processes acting on sinking particles collected during summer in the Beaufort Sea. These processes, which should gradually increase as ice-free waters increase in extent and duration (NSIDC, 2012), appear to destroy most of the unsaturated components of organisms initially present in the settling material - thus strongly altering their lipid signature. Although it is generally considered that sinking particles are the main contributors to the sedimentary record (Wakeham and Lee, 1989), it may be noted that zooplanktonic monounsaturated $n$-alcohols and their photooxidation products (present in very high proportion in these particles) were totally absent in the underlying surface sediments (Rontani et al., 2012a). The disappearance of those products as they transit through the aphotic layer of the water column might result from the involvement of free radical oxidation processes (induced by the cleavage of photochemically produced hydroperoxides), rather than from biodegradation processes limited by the photochemical alteration of attached bacteria. In the future, it will thus be essential to take into account the effects of abiotic degradation processes (relatively ignored until now in the literature) within sedimentary palaeoenvironmental reconstructions.

Acknowledgements. This study was conducted as part of the MALINA Scientific Program funded by ANR (Agence Nationale pour la Recherche) and French and European Space Agencies. Sediment trap samples were obtained through the Long-Term Oceanic Observatories Program of the ArcticNet Network of Centres of Excellence (NCE) of Canada. We would like to thank M. Babin, chief scientist of the cruise and coordinator of the MALINA program. This work was carried out in the framework of the transverse axis DEBAT (DEgradation Biotique et Abiotique de la maTière organique en milieu marin: processus et interactions) of the MIO. Thanks are due to S. Belt and G. J. M. Versteegh for their helpful and useful comments.

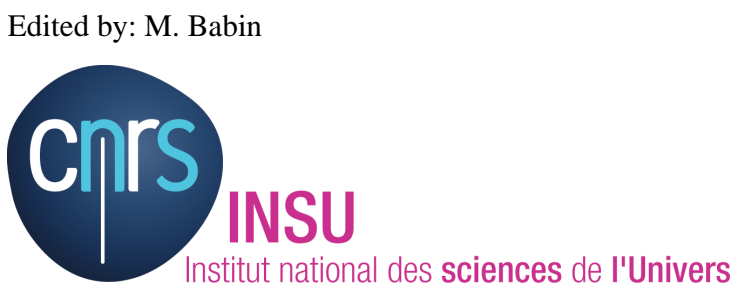

The publication of this article is financed by CNRS-INSU. 


\section{References}

Albers, C. S., Kattner, G., and Hagen, W.: The compositions of wax esters, triacylglycerols and phospholipids in Arctic and Antarctic copepods: evidence of energetic adaptation, Mar. Chem., 55, 347-358, 1996.

Arrigo, K. R., van Dijken, G., and Pabi, S.: Impact of a shrinking Arctic ice cover on marine primary production, Geophys. Res. Lett., 35, L19603, doi:10.1029/2008GL035028, 2008.

Bacon, M. P., Huh, C. A., Fleer, A. P., and Deuser, W. G.: Seasonality in the flux of natural radionuclides and plutonium in the deep Sargasso Sea, Deep-Sea Res., 32, 73-286, 1985.

Bayona, J. M., Farran, A., and Albaiges, J.: Steroid alcohols and ketones in coastal waters of the western Mediterranean: sources and seasonal variability, Mar. Chem., 27, 79-104, 1989.

Beutner, S., Bloedorn, B., Hoffman, T., and Martin, H. D.: Synthetic singlet oxygen quenchers, 226-241, edited by: Packer, L. and Sies, H., in: Methods in enzymology, 319, Academic press, 2000.

Bianchi, T. S.: The role of terrestrially derived organic carbon in the coastal ocean: A changing paradigm and the priming effect, Proc. Nat. Acad. Sci., 108, 19473-19481, 2011.

Bianchi, T. S. and Canuel, E. A.: Chemical Biomarkers in Aquatic Ecosystems, Princeton University Press, USA, 19471-19481, 2011.

Boutry, J., Alcaide, A., and Barbier, M.: De la présence d'un stérol en $\mathrm{C}_{26}$ d'un plancton marin végétal, C. R. Acad. Sci., Paris, 272, 1022-1023, 1971.

Bradshaw, S. A. and Eglinton, G.: Marine invertebrate feeding and the sedimentary lipid record, edited by: Engel, M. H. and Macko, S. A., Org. Geochem., Plenum Press, New York, 225-235, 1993.

Bradshaw, S. A., O'Hara, S. C. M., Corner, E. D. S., and Eglinton, G.: Changes in lipids during simulated herbivorous feeding by the marine crustacean Neomysis integer, J. Mar. Biol. Assoc. UK, 70, 225-243, 1990.

Brunskill, G. J.: Environmental features of the Mackenzie system, in: The ecology of river systems, edited by: Davis, B. R. and Walker, W. F., Dordrecht, The Netherlands, Dr. W. Junk Publications, 435-471, 1986.

Christodoulou, S., Marty, J.-C., Miquel, J.-C., Volkman, J. K., and Rontani, J.-F.: Use of lipids and their degradation products as biomarkers for carbon cycling in the northwestern Mediterranean Sea, Mar. Chem., 113, 25-40, 2009.

Christodoulou, S., Joux, F., Marty, J.-C., Sempéré, R., and Rontani, J.-F.: Comparative study of UV and visible light induced degradation of lipids in non-axenic senescent cells of Emiliania huxleyi, Mar. Chem., 119, 139-152, 2010.

Cuny, P. and Rontani, J.-F.: On the widespread occurrence of 3methylidene-7,11,15-trimethylhexadecan-1,2-diol in the marine environment: a specific isoprenoid marker of chlorophyll photodegradation, Mar. Chem., 65, 155-165, 1999.

Cuny, P., Romano, J.-C., Beker, B., and Rontani, J.-F.: Comparison of the photo degradation rates of chlorophyll chlorin ring and phytol side chain in phytodetritus: is the phytyldiol versus phytol ratio (CPPI) a new biogeochemical index?, J. Exp. Mar. Biol. Ecol., 237, 271-290, 1999.

Cuny, P., Marty, J.-C., Chiaverini, J., Vescovali, I., Raphel, D., and Rontani, J.-F.: One-year seasonal survey of the chlorophyll photodegradation process in the Northwestern Mediterranean sea, Deep Sea Res., II 49, 1987-2005, 2002.
Dahl, T. A., Midden, W. R., and Hartman, P. E.: Comparison of killing of Gram-negative and Gram-positive bacteria by pure singlet oxygen, J. Bacteriol., 171, 2188-2194, 1989.

De Leeuw, J. W. and Baas, M.: Early stage diagenesis of steroids, in: Biological Markers in the Sedimentary Record, edited by: Johns, R. B., Elsevier, 101-123, 1986.

Forest, A., Stemmann, L., Picheral, M., Burdorf, L., Robert, D., Fortier, L., and Babin, M.: Size distribution of particles and zooplankton across the shelf-basin system in southeast Beaufort Sea: combined results from an Underwater Vision Profiler and vertical net tows, Biogeosciences, 9, 1301-1320, doi:10.5194/bg-91301-2012, 2012a.

Forest, A., Babin, M., Stemmann, L., Picheral, M., Sampei, M., Fortier, L., Gratton, Y., Bélanger, S., Devred, E., Sahlin, J., Doxaran, D., Joux, F., Ortega-Retuerta, E., Jeffrey, W. H., Martín, J., Gasser, B., and Miquel, J. C.: Ecosystem function and particle flux dynamics across the Mackenzie Shelf (Beaufort Sea, Arctic Ocean): an integrative analysis of spatial variability and biophysical forcings, Biogeosciences Discuss., 9, 10883-10960, doi:10.5194/bgd-9-10883-2012, 2012b.

Frankel, E. N.: Lipid Oxidation, the Oily Press, Dundee, 1-303, 1998.

Frey, K. E. and McClelland, J. W.: Impacts of permafrost degradation on Arctic river biogeochemistry, Hydrol. Processes, 23, 169-182, 2009.

Frimer, A. A.: The reaction of singlet oxygen with olefins: the question of mechanism. Chem. Rev., 79, 359-387, 1979.

Gagosian, R. B., Peltzer, E. T., and Merrill, J. T.: Long-range transport of terrestrially derived lipids in aerosols from the south $\mathrm{Pa}$ cific, Nature, 325, 800-803, 1987.

Graeve, M., Kattner, G., and Hagen, W.: Diet-induced changes in the fatty acid composition of Arctic herbivorous copepods, J. Exp. Mar. Biol. Ecol., 182, 97-110, 1994.

Hansen, J., Ruedy, R., Sato, M., and Lo, K.: GISS Surface Temperature Analysis (GISTEMP): Global Temperature in 2011, Trends, and Prospects, http://data.giss.nasa.gov/gistemp/2011/, 2012.

Harvey, H. R., Eglinton, G., O'Hara, S. C. M., and Corner, E. D. S.: Biotransformation and assimilation of dietary lipids by Calanus feeding on a dinoflagellate, Geochim. Cosmochim. Acta, 51, 3031-3040, 1987.

Harwood, J. L. and Russell, N. L.: Lipids in Plants and Microbes, George Allen and Unwin, London, 1-162, 1984.

Heussner, S., Ratti, C., and Carbonne, J.: The PPS 3 time series sediment traps and the trap sample processing techniques used during the ECOMARGE experiment, Cont. Shelf Res., 10, 943958, 1990.

Hill, P. S.: Controls on floc size in the sea, Oceanogr., 11, 13-18, 1998.

Hill, P. R., Blasco, S. M., Harper, J. R., and Fissel, D. B.: Sedimentation on the Canadian Beaufort Shelf, Cont. Shelf Res., 11, 821-842, 1991.

Hill, V., Cota, G., and Stockwell, D.: Spring and summer phytoplankton communities in the Chukchi and eastern Beaufort Seas, Deep-Sea Res., 52, 3369-3385, 2005.

Horner, R. A. and Schrader, G. C.: Relative contributions of ice algae, phytoplankton and benthic microalgae to primary production in nearshore regions of the Beaufort Sea, Arctic, 35, 485$503,1982$. 
Horspool W. and Armesto D.: Organic Photochemistry: A Comprehensive Treatment, Ellis Horwood, Chichester, UK, 1-521, 1992.

Kawamura, K. and Gagosian, R. B.: Implication of $\omega$-oxocarboxylic acids in the remote marine atmosphere for photo-oxidation of unsaturated fatty acids, Nature, 325, 330-332, 1987.

Keweloh, H. and Heipieper, H. J.: Trans-unsaturated fatty acids in bacteria, Lipids, 31, 129-137, 1996.

Knap, A., Michaels, A., Close, A., Ducklow, H., and Dickson, A.: Protocols for the Joint Global Ocean Flux Study (JGOFS) core measurements, JGOFS Report, 19, 155-162, 1996.

Kolattukudy, P. E.: Lipid polymers and associated phenols, their chemistry, biosynthesis, and role in pathogenesis, Recent Adv. Phytochem., 77, 185-246, 1977.

Lalande, C., Bélanger, S., and Fortier, L.: Impact of a decreasing sea ice cover on the vertical export of particulate organic carbon in the northern Laptev Sea, Siberian Arctic Ocean, Geophys. Res. Lett., 36, L21604, doi:10.1029/2009GL040570, 2009.

Leblond, J. D. and Chapman, P. J.: A survey of the sterol composition of the marine dinoflagellates Karenia brevis, Karenia mikimotoi and Karlodinium micrum: distribution of sterols within other members of the class dinophyceae, J. Phycol., 38, 670-682, 2002.

Lee, C., Gagosian, R. B., and Farrington, J. W.: Geochemistry of sterols in sediments from Black Sea and the southwest African shelf and slope, Org. Geochem., 2, 103-113, 1980.

Lee, R. F. and Nevenzel, J. C.: Wax esters in the marine environment: origin and composition of the wax from the Bute Inlet, British Columbia, J. Fish. Res. Bd. Can., 36, 1519-1523, 1979.

Lee, R. F., Hagen, W., and Kattner, G.: Lipid storage in marine zooplankton. Mar. Ecol. Prog. Ser., 307, 273-306, 2006.

Lütjohann, D.: Sterol autoxidation: from phytosterols to oxyphytosterols, Brit. J. Nutr., 91, 3-4, 2004.

Macdonald, R. W., Solomon, S. M., Cranston, R. E., Welch, H. E., Yunker, M. B., and Gobeil, C.: A sediment and organic carbon budget for the Canadian Beaufort Shelf, Mar. Geol., 144, 255273, 1998

Mansour, M. P., Volkman, J. K., Jackson, A. E., and Blackburn, S. I.: The fatty acid and sterol composition of five marine dinoflagellates, J. Phycol., 35, 710-720, 1999.

Marchand, D. and Rontani, J.-F.: Characterisation of photooxidation and autoxidation products of phytoplanktonic monounsaturated fatty acids in particulate matter and recent sediments, Org. Geochem., 32, 287-304, 2001.

Marchand, D. and Rontani, J.-F.: Visible light-induced oxidation of lipid components of purple sulphur bacteria: a significant process in microbial mats, Org. Geochem., 34, 61-79, 2003.

McCave, I. N.: Size spectra and aggregation of suspended particles in the ocean, Deep-Sea Res., 31, 329-352, 1984.

Mihara, S. and Tateba, H.: Photosensitized oxygenation reactions of phytol and its derivatives, J. Org. Chem., 51, 1142-1144. 1986.

Milliman, J. D. and Meade, R. H.: World-wide delivery of river sediment to the oceans, J. Geol., 91, 1-21, 1983.

Najdek, M., Puskaric, S., and Bochdansky, A.: Contribution of zooplankton lipids to the flux of organic matter in the northern Adriatic Sea, Mar. Ecol. Prog. Ser., 111, 241-249, 1994.

NSIDC: National Snow and Ice Data Center, Arctic Sea Ice News and Analysis, http://nsidc.org/arcticseaicenews/, 2012.

O'Brien, M. C., Macdonald, R. W., Melling, H., and Iseki, K.: Particle fluxes and geochemistry on the Canadian Beaufort Shelf: implications for sediment transport and deposition, Cont. Shelf Res., 26, 41-81, 2006.

Pokorny, J.: Major factors affecting the autoxidation of lipids, 141206, edited by: H. W.-S. Chan, in: Autoxidation of unsaturated lipids, Academic Press, 1987.

Prahl, F. G., Eglinton, G., Corner, E. D. S., O’Hara, S. C. M., and Forsberg, T. E. V.: Changes in plant lipids during passage through the gut of Calanus, J. Mar. Biol. Assoc. UK, 64, 317-334, 1984.

Rachold, V., Eicken, H., Gordeev, V. V., Grigoriev, M. N., Hubberten, H. W., Lisitzin, A. P., Shevchenko, V. P., and Schirrmeister, L.: Modern terrigenous organic carbon input to the Arctic Ocean, in: The Organic Carbon Cycle in the Arctic Ocean, edited by: Stein, R. S. and Macdonald, R. W., Springer, New York, 33 55, 2004.

Rontani, J.-F. and Marchand, D.: $\Delta^{5}$-Stenol photoproducts of phytoplanktonic origin: a potential source of hydroperoxides in marine sediments?, Org. Geochem., 31, 169-180, 2000.

Rontani, J.-F. and Volkman, J. K.: Phytol degradation products as biogeochemical tracers in aquatic environments, Org. Geochem., 34, 1-35, 2003.

Rontani, J.-F. and Volkman, J. K.: Lipid characterization of coastal hypersaline cyanobacterial mats from the Camargue (France), Org. Geochem., 36, 251-272, 2005.

Rontani, J.-F., Grossi, V., Faure, R., and Aubert, C.: "Bound" 3-methylidene-7,11,15-trimethylhexadecan-1,2-diol: a new isoprenoid marker for the photodegradation of chlorophyll- $a$ in seawater, Org. Geochem., 21, 135-142, 1994.

Rontani, J.-F., Raphel, D., and Cuny, P.: Early diagenesis of the intact and photooxidized chlorophyll phytyl chain in a recent temperate sediment, Org. Geochem., 24, 825-832, 1996.

Rontani, J.-F., Cuny, P., and Aubert, C.: Rates and mechanism of light-dependent degradation of sterols in senescent cells of phytoplankton, J. Photochem. Photobiol., A: Chem., 111, 139-144, 1997.

Rontani, J.-F., Cuny, P., and Grossi, V.: Identification of a pool of lipid photoproducts in senescent phytoplanktonic cells, Org. Geochem., 29, 1215-1225, 1998.

Rontani, J.-F., Koblizek, M., Beker, B., Bonin, P., and Kolber, Z.: On the origin of cis-vaccenic photodegradation products in the marine environment, Lipids, 38, 1085-1092, 2003.

Rontani, J.-F., Zabeti, N., and Wakeham, S. G.: The fate of marine lipids: Biotic vs. abiotic degradation of particulate sterols and alkenones in the Northwestern Mediterranean Sea, Mar. Chem., 113, 9-18, 2009.

Rontani, J.-F., Zabeti, N., and Wakeham, S. G.: Degradation of particulate organic matter in the equatorial Pacific Ocean: biotic or abiotic?, Limnol. Oceanogr., 56, 333-349, 2011.

Rontani, J.-F., Charriere, B., Petit, M., Vaultier, F., Heipieper, H., Link, H., Chailloux, G., and Sempéré, R.: Degradation state of organic matter in surface sediments from the Southern Beaufort Sea: a lipid approach, Biogeosciences, 9, 3513-3530, doi:10.5194/bg-9-3513-2012, 2012a.

Rontani, J.-F., Charriere, B., Sempéré, R., Doxaran, D., Vaultier, F., Vonk, J. E., and Volkman, J. K.: Lipid biomarker evidence for extensive biotic and abiotic degradation of terrestrial organic matter in Arctic coastal waters, Geochim. Cosmochim. Acta, submitted, 2012b.

Saliot, A., Parrish, C. C., Sadouni, N., Bouloubassi, I., Fillaux, J., and Cauwet, G.: Transport and fate of Danube Delta terrestrial 
organic matter in the Northwest Black Sea mixing zone, Mar. Chem., 79, 243-259, 2002.

Schaich, K. M.: Lipid oxidation: theoretical aspects, in: Bailey's Industrial Oil and Fat Products, Sixth edition, edited by: Shahidi, F., John Wiley \& Sons, 269-355, 2005.

Sicre, M.-A., Paillasseur, J. L., Marty, J.-C., and Saliot, A.: Characterization of seawater samples using chemometric methods applied to biomarker fatty acids, Org. Geochem., 12, 281-288, 1988.

Suwa, K., Kimura, T., and Schaap, A. P.: Reactivity of singlet molecular oxygen with cholesterol in a phospholipidic membrane matrix: a model for oxidative damage of membranes, Biochem. Biophys. Res. Commun., 75, 785-792, 1977.

Vallières, C., Retamal, L., Ramlal, P., Osburn, C. L., and Vincent, W. F.: Bacterial production and microbial food web structure in a large Arctic river and the coastal Arctic Ocean, J. Mar. Syst., 74, 756-773, doi:10.1016/j.jmarsys.2007.12.002, 2008.

Volkman, J. K.: A review of sterol markers for marine and terrigenous organic matter, Org. Geochem., 9, 83-99, 1986.

Volkman, J. K.: Sterols in microorganisms, Appl. Microbiol. Biotechnol., 60, 495-506, 2003.

Volkman, J. K., Corner, E. D. S., and Eglinton, G.: Transformations of biolipids in the marine food web and in underlying bottom sediments, Colloques Int. Cent. Natn. Rech. Scient., 293, 185197, 1980.

Volkman, J. K., Barrett, S. M., Blackburn, S. I., Mansour, M. P., Sikes, E. L., and Gelin, F.: Microalgal biomarkers: A review of recent research developments, Org. Geochem., 29, 1163-1179, 1998.

Vonk, J. E., van Dongen, B. E., and Gustafsson, O.: Selective preservation of old organic carbon fluvially released from sub-Arctic soils, Geophys. Res. Lett., 37, L11605, doi:10.1029/2010g1042909, 2010a.
Vonk, J. E., Sánchez-García, L., Semiletov, I., Dudarev, O., Eglinton, T., Andersson, A., and Gustafsson, Ö.: Molecular and radiocarbon constraints on sources and degradation of terrestrial organic carbon along the Kolyma paleoriver transect, East Siberian Sea, Biogeosciences, 7, 3153-3166, doi:10.5194/bg-73153-2010, 2010b.

Wakeham, S. G.: Reduction of stenols to stanols in particulate matter at oxic-anoxic boundaries in seawater, Nature, 342, 787-790, 1989.

Wakeham, S. G. and Lee, C.: Organic geochemistry of particulate matter in the ocean: The role of particles in oceanic sedimentary cycles, Org. Geochem., 14, 83-96, 1989.

Wakeham, S. G., Hedges, J. I., Lee, C., Peterson, M. L., and Hernes, P. J.: Compositions and transport of lipid biomarkers through the water column and surficial sediments of the EqPac Ocean, DeepSea Res., 44, 2131-2162, 1997.

Ward, P. F. V., Scott, T. W., and Dawson, R. M. C.: The hydrogenation of unsaturated fatty acids in the ovine digestive tract Biochem. J., 92, 60-68, 1964.

Wassmann, P. and Reigstad, M.: Future Arctic Ocean seasonal ice zones and implications for pelagic-benthic coupling, Oceanography, 24, 220-231, doi:10.5670/oceanog.2011.74, 2011.

Wassmann, P., Bauerfeind, E., Fortier, M., Fukuchi, M., Hargrave, B., Honjo, S., Moran, B., Noji, T., Nöthig, E. M, and Peinert, R.: Particulate organic carbon flux to the sea floor, edited by: Stein, R., MacDonald, R., in: The Organic Carbon Cycle in the Arctic Ocean, Springer-Verlag, New York, 101-138, 2004. 